\title{
UPAYA GURU PAI DALAM MENINGKATKAN HASIL BELAJAR MATERI MARI MEMBACA ALQURAN SURAT AT-TIN MELALUI METODE COOPERATIVE INTEGRATED READING AND COMPOSITION (CIRC) BAGI SISWA KELAS V SD NEGERI 1 SUNGAI AMBAWANG
}

\author{
NURYANTA \\ SD Negeri 1 Sungai Ambawang \\ e-mail.nury91668@gmail.com
}

\begin{abstract}
ABSTRAK
Penelitian ini bertujuan untuk meningkatkan hasil belajar materi mari membaca Alquran Surat at-Tin melalui metode Cooperative Integrated Reading And Composition (CIRC) bagi siswa kelas V SD Negeri 1 Sungai Ambawang. Jenis penelitian ini adalah Penelitian Tindakan Kelas dengan subjek penelitian siswa kelas V SD Negeri 1 Sungai Ambawang. Analisis kualitatif digunakan untuk data kualitatif yang berupa wawancara, catatan lapangan, dan dokumentasi tugas siswa. Hasil penelitian menunjukkan penerapan metode CIRC dapat meningkatkan kemampuan dan proses belajar membaca pemahaman siswa kelas V SD Negeri 1 Sungai Ambawang. Dari perbaikan tindakan ini terjadilah peningkatan proses yang dapat dilihat dari kondisi siswa yang lebih aktif dalam kegiatan pembelajaran. Peningkatan secara proses berdampak positif pada peningkatan kualitas produk. Hal ini berdasarkan tes membaca pemahaman meningkat, terbukti dengan nilai rata-rata siswa pratindakan sebesar 61,58 , dengan pencapaian KKM 57,90\%, pascatindakan siklus I sebesar 71,05 dengan pencapaian KKM 68,42\% dan pascatindakan siklus 2 sebesar 81,58 dengan pencapaian KKM 89,47\%.
\end{abstract}

Kata kunci: Membaca Alquran, Metode CIRC.

\section{ABSTRACT}

This study aims to improve the learning outcomes of let's read the Koran Surat at-Tin through the Cooperative Integrated Reading And Composition (CIRC) method for fifth grade students of SD Negeri 1 Sungai Ambawang. This type of research is Classroom Action Research with the research subjects of fifth grade students of SD Negeri 1 Sungai Ambawang. Qualitative analysis was used for qualitative data in the form of interviews, field notes, and documentation of student assignments. The results showed that the application of the CIRC method could improve the reading comprehension ability and learning process of fifth graders at SD Negeri 1 Sungai Ambawang. From the improvement of this action, there is an improvement in the process which can be seen from the condition of students who are more active in learning activities. Process improvement has a positive impact on improving product quality. This is based on the increased reading comprehension test, as evidenced by the average score of preaction students of 61.58 , with the achievement of KKM 57.90\%, post-action cycle I of 71.05 with achievement of KKM $68.42 \%$ and post-action cycle 2 of 81,58 with the achievement of KKM $89.47 \%$.

Keywords: Reading the Koran, CIRC Method.

\section{PENDAHULUAN}

Kemampuan membaca merupakan hal yang terpenting bagi kehidupan manusia, terutama di era globalisasi saat sekarang ini. Setiap orang menginginkan untuk bisa membaca agar memperoleh informasi. Semua orang dituntut untuk bisa membaca terutama dalam membaca Alquran bagi umat Islam. Pembelajaran Alquran merupakan suatu kewajiban yang harus dilaksanakan dan dikembangkan bagi setiap individu muslim, karena terkait langsung dengan ibadah ritual seperti shalat, haji, dan berdo'a. Inilah yang menjadi argumentasi mendasar ditetapkannya ketrampilan membaca sebagai prioritas pertama dan utama dalam pendidikan Islam. Seperti dalam firman Allah SWT dalam Alquran surat al-Alaq ayat 1-5 


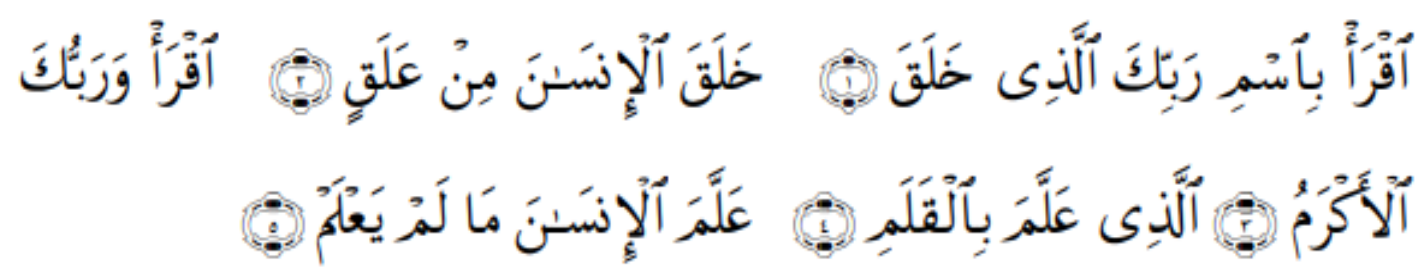

Artinya: Bacalah dengan (menyebut) nama Tuhanmu yang Menciptakan, Dia telah menciptakan manusia dari segumpal darah. Bacalah, dan Tuhanmulah yang Maha pemurah, Yang mengajar (manusia) dengan perantaran kalam, Dia mengajarkan kepada manusia apa yang tidak diketahuinya (Q.S. al-'Alaq/96: 1-5).

Membaca adalah melihat serta memahami isi dari apa yang tertulis (dengan melisankan atau hanya dalam hati). Definisi lain menjelaskan bahwa membaca adalah mengeja atau melafalkan apa yang tertulis. Membaca pada hakikatnya adalah suatu yang rumit yang melibatkan banyak hal, tidak hanya sekedar melafalkan tulisan,tetapi juga melibatkan aktivitas visual, pikiran, psikolinguistik, dan metakognitif (Sapri, 2017: 45). Sebagai proses visual, membaca merupakan proses menerjemahkan simbul tulis (huruf) kedalam kata-kata lisan. Sebagai proses berfikir, membaca mencakup aktivitas pengenalan kata, pemahaman literal, interpretasi, membaca kritis, dan pemahaman kreatif (Farida Rahim. 2007: 2)

Dalam hal ini guru mempunyai peranan yang penting untuk membina siswa dalam meningkatkan keterampilan membaca Alquran. Mengajarkan membaca Alquran kepada siswa bukanlah pekerjaan mudah. Seorang guru perlu memiliki suatu keterampilan atau kompetensi yang baik untuk memajukan keterampilan membaca Alquran siswa-siswanya.

Dengan keterampilan membaca Alquran yang memadai, mereka akan lebih mudah mendapatkan informasi dari berbagai sumber. Pada pelaksanaan pembelajaran membaca Alquran, biasanya guru menggunakan metode pembelajaran tradisional. Guru hanya memberikan tugas kepada siswa untuk membaca teks. Sebelum kegiatan dilaksanakan, guru berceramah tentang informasi yang dianggap penting berkaitan dengan apa yang harus dilakukan siswa.

Kegiatan membaca dilakukan dari awal sampai akhir teks, yang selanjutnya siswa diminta untuk mengerjakan soal-soal yang sudah disiapkan guru. Heru Wijaya (2007: 119) menyimpulkan dalam penelitiannya bahwa metode membaca tradisional kurang efektif dalam pembelajaran membaca Alquran di SD. Selanjutnya dikatakan bahwa siswa yang mengalami kesukaran dalam membaca bacaan dengan pemahaman yang memadai disebabkan oleh metode membaca yang kurang tepat ketika mereka membaca.

Walaupun metode tradisional dianggap kurang efektif, kenyataan di sekolah menunjukkan bahwa metode ini masih sering digunakan. Suatu hal yang mungkin menjadi penyebabnya adalah guru kurang bervariasi dalam menggunakan metode membaca. Hal inilah yang menyebabkan keterampilan siswa dalam membaca Alquran rendah. Hal yang sama juga terjadi di kelas V SD Negeri 1 Sungai Ambawang. Pembelajaran Pendidikan Agama Islam di kelas V SD Negeri 1 Sungai Ambawang masih menggunakan metode konvensional dimana proses pembelajaran masih berpusat pada guru sehingga siswa menjadi pasif. Berdasarkan pengamatan dan wawancara dengan guru kelas V SD Negeri 1 Sungai Ambawang, menunjukkan bahwa kemampuan siswa kelas V dalam membaca, khususnya membaca Alquran masih rendah.

Terbukti dengan rendahnya nilai tes pratindakan membaca Alquran yang dilakukan oleh peneliti. Belum mampunya siswa dalam membaca Alquran ditandai dengan kurangnya siswa dalam memahami isi bacaan, menentukan tema bacaan, dan memperoleh informasi dari teks yang telah dibaca. Ketika siswa diberi pertanyaan mengenai isi bacaan yang dibaca siswa tidak dapat menjawab dengan cepat dan harus membuka kembali bahan bacaan. Permasalahanpermasalahan tersebut harus segera dicarikan solusinya, karena sangat mempengaruhi banyak sedikitnya informasi dan pengetahuan yang diterima siswa dari berbagai sumber tertulis. 
Dengan kata lain permasalahan yang paling utama untuk segera diatasi adalah permasalahan rendahnya kemampuan membaca Alquran pada siswa kelas V SD Negeri 1 Sungai Ambawang. Pada kenyataannya pembelajaran membaca Alquran di SD Negeri 1 Sungai Ambawang belum melibatkan siswa secara aktif. Pembelajaran membaca Alquran yang selama ini dilakukan masih menggunakan metode konvensional yaitu dengan memberikan teks bacaan kepada siswa, kemudian siswa menjawab pertanyaan mengenai bacaan tersebut.

\section{METODE PENELITIAN}

Dalam penelitian ini prosedur yang utama adalah perencanaan (planning), pelaksanaan (acting), pengamatan (observing) dan refleksi (reflecting), itu merupakan empat langkah utama dalam pelaksanaan Penelitan Tindakan Kelas (PTK) sering disebut dengan istilah satu siklus (Susilo, 2009:19). Untuk lebih jelas berikut ini dikemukakan model siklus Penelitian Tindakan Kelas (PTK):

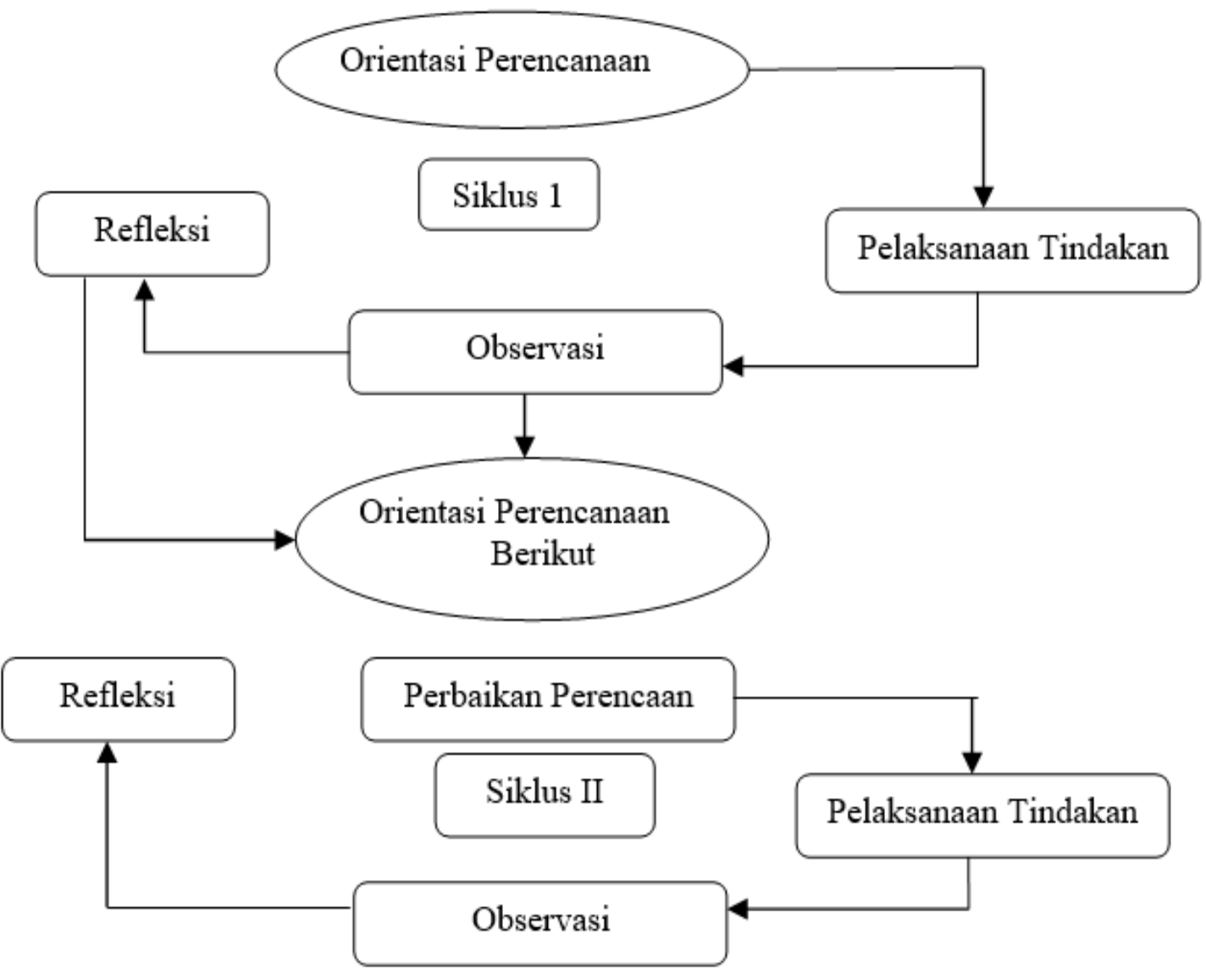

Gambar 1. Model siklus Penelitian Tindakan Kelas (PTK)

Dari gambar di atas, langkah-langkah pelaksanaan Penelitian Tindakan Kelas (PTK) yang harus dilakukan peneliti sebagai berikut: Perencanaan (planning) mencakup hal-hal sebagai berikut: (1) Identifikasi masalah, (2) Analisis penyebab adanya masalah (3) Pengembangan bentuk tindakan (aksi) sebagai pemecahan masalah. Pelaksanaan tindakan (acting) yaitu implemantasikan tindakan dalam proses pembelajaran sesuai dengan skenario pembelajaran yang telah dibuat. Observasi (observing) yaitu Kegiatan observasi ini dilakukan dimaksudkan untuk mengetahui atau memperoleh gambaran lengkap secara objektif tentang perkembangan proses pembelajaran sekaligus untuk mengetahui pengaruh dari tindakan yang dipilih terhadap kondisi kelas dalam bentuk data. Atau lebih ringkasnya bisa dikatakan sebagai 
kegiatan merekam informasi dampak dari pelaksanaan tindakan baik dengan atau tampa alat bantu. Refleksi (reflecting) yaitu dilakukan untuk mengadakan upaya evaluasi yang dilakukan oleh peneliti. Pada kegiatan refleksi ini ditelaah aspek-aspek mengapa, bagaiman, dan sejauh mana tindakan yang dilakukan memperbaiki masalah secara bermakna. Melalui refleksi inilah peneliti akan memutuskan untuk melakukan siklus lanjuatan ataukah berhenti karena masalahnya sudah terpecahkan.

\section{HASIL DAN PEMBAHASAN}

\section{Hasil Penelitian Siklus I}

Refleksi Tahap keempat dalam penelitian tindakan kelas ini adalah refleksi. Refleksi merupakan kegiatan untuk mengungkapkan kembali apa yang sudah dilakukan, menguraikan informasi, mengkaji secara mendalam kekurangan dan kelebihan tindakan tersebut. Dalam tahap refleksi, peneliti dan guru melakukan evaluasi proses pembelajaran membaca Alquran yang telah dilakukan. Hal ini dilakukan untuk mengetahui seberapa besar peningkatan kemampuan membaca Alquran siswa dengan penerapan metode CIRC. Hasil tes kemampuan membaca Alquran pascatindakan siklus I mengalami peningkatan dibandingkan dengan hasil tes pratindakan, akan tetapi peningkatan tersebut belum dinilai baik oleh guru dan peneliti karena dalam kriteria keberhasilan dalam penelitian ini yaitu $75 \%$ dari jumlah siswa yang mengikuti proses belajar mengajar telah mencapai taraf keberhasilan minimal sebesar 65 .

Berdasarkan dari tes pascatindakan siklus I dapat diketahui adanya peningkatan nilai rerata dari tes pratindakan ke tes pascatindakan siklus I yaitu dari 61,58 menjadi 71,05. Sedangkan siswa yang sudah tuntas tes kemampuan membaca Alquran yang sesuai dengan KKM yaitu meningkat 10,52\%, dari 57,90\% menjadi 68,42\%.

Meskipun demikian, peningkatan tersebut belum maksimal karena dinilai belum mencapai kriteria keberhasilan dalam penelitian yang sudah ditetapkan peneliti dan guru yaitu antara $75 \%$ dari jumlah siswa yang mengikuti proses belajar mengajar telah mencapai taraf keberhasilan minimal sebesar 65. Sementara pada tes pascatindakan siklus I, siswa yang telah mencapai taraf keberhasilan minimal 73,45\%, sehingga dalam penelitian tindakan kelas siklus I belum dikatakan berhasil. Selain itu, dalam tindakan siklus I masih terdapat kendala-kendala yang dialami siswa selama proses pembelajaran membaca Alquran.

Berdasarkan hasil obsevasi dan catatan lapangan, kendala-kendala yang dialami siswa adalah sebagai berikut: (1) beberapa siswa belum sepenuhnya paham dengan tahap-tahap metode CIRC dan nampaknya siswa belum terbuka dengan guru. (2) masih ada beberapa siswa yang belum ikut aktif dalam kegiatan diskusi kelompok.(3) waktu yang diberikan guru kepada siswa untuk mengerjakantugas terlalu singkat, sehingga siswa mengalami kesulitan dalam menyelesaikan tugas. Permasalahan-permasalahan tersebut harus segera diatasi agar upaya meningkatkan kemampuan membaca Alquran dengan penerapan metode CIRC dapat berhasil sesuai rencana.

Dalam mengatasi masalah tersebut, peneliti juga harus cermat karena jika permasalahan yang pertama sulit diatasi maka akan menghambat pelaksanaan tindakan selanjutnya. Meskipun demikian, secara keseluruhan pelaksanaan kegiatan proses belajar mengajar membaca Alquran dengan penerapan metode CIRC berjalan dengan lancar. Disamping kendala-kendala tersebut, beberapa hal yang positif juga telah diraih oleh siswa dalam proses tindakan siklus I ini. Beberapa hal positif itu antara lain: (1) siswa mulai nampak antusias dalam mengikuti pembelajaran membaca Alquran, (2) siswa mulai aktif dalam pembelajaran, dan (3) jiwa kompetitif siswa dalam bekerjasama mulai tumbuh. Berdasarkan hasil pengamatan, hasil tes yang telah diperoleh, serta hasil refleksi yang telah dilakukan, hasil yang diperoleh dirasakan belum maksimal.

Untuk itu, disusunlah rencana perbaikan yang akan dilaksanakan pada siklus selanjutnya, yakni siklus kedua. Adapun perbaikan yang akan diterapkan pada siklus II adalah dengan menambahkan reward kepada tiga kelompok yang memperoleh nilai terbaik dalam 
kegiatan diskusi kelompok agar siswa menjadi lebih antusias dan lebih aktif selama kegiatan pembelajaran membaca Alquran.

\section{Hasil Penelitian Siklus II}

Tahap keempat dalam penelitian tindakan kelas ini adalah refleksi. Dalam kegiatan refleksi, guru dan peneliti mengevaluasi implementasi tindakan dan menganalisis dampak implementasi tindakan yang telah dilaksanakan dalam dua pertemuan tersebut. Hal ini dilakukan untuk mengetahui seberapa besar peningkatan kemampuan 66 siswa dalam kegiatan membaca Alquran dan keberhasilan pembelajaran dengan penerapaan metode CIRC pada siklus 2. Pada siklus 2, nilai rerata tes pascatindakan mengalami peningkatan dari siklus I. Nilai rerata tes membaca Alquran siklus 2 adalah 81,58 yakni meningkat sebesar 10,53 atau dari siklus I, sedangkan siswa yang sudah mencapai kriteria ketuntasan minimal meningkat $21,05 \%$, dari $68,42 \%$ menjadi $89,47 \%$. Hasil dirasa sudah cukup memuaskan, karena indikator keberhasilan dalam penelitian ini sudah tercapai.

\section{Pembahasan Penelitian}

Tingkat kemampuan siswa dalam membaca Alquran dalam penelitian ini dilihat dari keberhasilan siswa dalam mengerjakan soal tes membaca Alquran yang diadakan pada akhir masing-masing siklus. Terdapat 20 butir soal pilihan ganda yang harus dikerjakan oleh siswa, baik pada siklus I maupun siklus 2. Soal tersebut dibuat berdasarkan taksonomi Burret yang digunakan sebagai pedoman penyusunan tes membaca Alquran sesuai tujuan pembelajaran yang telah dirumuskan.

\section{Peningkatan Kemampuan Siswa dalam Membaca Alquran pada Siklus I}

Berdasarkan hasil tes pascatindakan siklus I, kemampuan membaca siswa dalam membaca Alquran meningkat dibanding pada tes yang 67 dilakukan pada saat pratindakan. Peningkatan kemampuan siswa dalam membaca Alquran ditunjukkan dengan peningkatan nilai rerata dari 57,90 pada tes pratindakan menjadi 71,05 pada tes pasca tindakan siklus I. Pada siklus ini nilai rerata meningkat sebesar 9,47 atau 13,33\% dari tes pratindakan. Sementara itu, siswa yang telah mencapai KKM juga mengalami peningkatan 10,52\%, dari 57,90\% menjadi $68,42 \%$.

Rini Astuti (2013: 351) pengembangan kemampuan membaca, menulis dan menghafal. Mengajarkan membaca Alquran kepada anak-anak memerlukan cara tersendiri apalagi jika anak tersebut adalah anak berkebutuhan khusus. Kesulitan membaca Alquran yang dialami oleh anak berkebutuhan khusus belum mendapat perhatian dari guru dan juga orang tua. Hal ini merupakan kondisi yang memprihatinkan dan menjadi perhatian peneliti untuk melakukan tindakan yang dapat mengubah kondisi. Sedang (Abd. Rosyid. 2019: 22) Penguasaan membaca huruf hijaiyyah dan mengenal huruf sangat berperan penting dalam mengembangkan aspek kemampuan bahasa terutama bahasa arab. Seorang anak yang tahu huruf hijaiyyah, maka anak tersebut secara mudah dapat membaca Alquran dengan baik dan lancar dan tidak akan mempunyai hambatan dalam membaca Alquran.

Pengajaran Alquran tidak dapat disamakan dengan pengajaran membaca dan menulis seperti pada umumnya yang diterapkan dalam mata pelajaran lainnya di sekolah dasar maupun menengah, karena dalam pengajaran Alquran, anak-anak terlebih dahulu belajar huruf-huruf hijaiyah dan kata-kata yang tidak mereka pahami artinya (Muhib \& Muhammad Khair. 2005: 14). Yang paling penting dalam pengajaran Alquran ini ialah keterampilan membaca Alquran dengan baik sesuai dengan kaidah yang disusun dalam Ilmu Tajwid. Untuk dapat membaca dengan baik. Sebelum itu hendaknya sudah memahami dan dapat menggunakan berbagai tanda baca, dapat membunyikan symbol-simbol huruf dan kata sesuai dengan bunyi yang diucapkan oleh orang Arab. Kita mencontoh bunyi yang diucapkan oleh orang arab karena bahasa Alquran adalah bahasa Arab. 


\section{Peningkatan Kemampuan Siswa dalam Membaca Alquran pada Siklus 2 Pada siklus 2,}

Kemampuan siswa dalam membaca Alquran meningkat dibandingkan pada tes pascatindakan siklus I. Peningkatan kemampuan siswa dalam membaca Alquran ditunjukkan dengan peningkatan nilai rerata dari 71,84 pada tes pascatindakan siklus I menjadi 80,26 pada tes pascatindakan siklus 2. Pada siklus ini, nilai rerata meningkat sebesar 10,53 atau 12,91\% dari tes pascatindakan siklus I. Sementara itu, siswa yang telah mencapai KKM juga meningkat $21,05 \%$, dari 68,42\% menjadi 89,47\%. c. Peningkatan Kemampuan Siswa dalam Membaca Alquran pada Siklus I dan Siklus 2 Kemampuan membaca Alquran siswa mengalami peningkatan dari waktu ke waktu. Hal ini dibuktikan dengan peningkatan yang dialami siswa dalam pembelajaran membaca Alquran baik secara proses maupun secara produk. Secara proses peningkatan dapat dilihat dari adanya perubahan kearah perbaikan dan meningkatnya tindak belajar, meliputi peningkatan keaktifan dan antusias siswa dalam mengikuti pembelajaran. Selain itu, guru juga memberikan respon positif karena penerapan metode CIRC dapat mengaktivasi siswa aktif dalam proses pembelajaran dan mampu bekerja sama serta menjadikan suasana kelas lebih hidup. Peningkatan membaca Alquran siswa secara produk ditunjukkan dengan nilai tes membaca Alquran siswa pada setiap akhir siklus. Nilai rerata pratindakan sebesar 61,58 sedangkan pada siklus I sebesar 71,05. Hal ini berarti terjadi kenaikan sebesar 9,47 atau 13,33\% dari nilai rerata pratindakan. Sementara itu, pada siklus 2 juga terjadi peningkatan nilai rerata tes membaca Alquran siswa. Nilai rerata tes pascatindakan siklus 2 sebesar 81,58. Pada siklus 2 nilai rerata meningkat sebesar 10,53 atau sebesar 12,91\% dari nilai rerata pascatindakan siklus I. Sedangkan siswa yang sudah mencapai KKM juga semakin meningkat, pada tes pratindakan siswa yang sudah mencapai KKM baru 57,90\%, selanjutnya pada tes pascatindakan siklus I siswa yang sudah mencapai KKM meningkat $21 \%$, dari $57,90 \%$ menjadi $68,42 \%$, dan terakhir pada tes pascatindakan siklus 2 meningkat $21,05 \%$, dari $68,42 \%$ menjadi $89,47 \%$. Hal ini dirasa sudah cukup memuaskan bagi guru dan peneliti, karena indikator keberhasilan sudah tercapai. Penggunaan metode CIRC dalam proses belajar mengajar membaca Alquran siswa kelas $\mathrm{V}$ mendapat respon positif dari guru maupun para siswa.

Seorang guru juga sangat perlu memperhatikan beberapa faktor yang mempengaruhi siswa dalam belajar khusunya dalam belajar membaca Alquran, yaitu : 1) Faktor Intern (faktor yang berasal dari dalam diri siswa), yaitu Fisiologis seperti kondisi fisik dan kondisi panca indra dan Psokologis seperti bakat, minat, kecerdasan, motivasi, dan Kemampuan Kognitif (pengetahuan). 2) Faktor ekstern (faktor yang berasal dari luar diri siswa) yaitu Faktor lingkungan keluarga seperti orang tua, suasana rumah, dan keadaan sosial ekonomi. 3) Lingkungan sekolah seperti interaksi antara guru dan siswa, cara penyajian pelajaran, hubungan antar siswa, pelajaran yang sesuai dengan standar ukuran, media komunikasi, keadaan gedung, dan metode belajar. 4) Lingkungan masyarakat seperti media masa, teman bergaul, kegiatan dalam masyarakat, dan cara hidup lingkungan (M. Ngalim Purwanto. 2002: 108).

Penelitian tindakan kelas ini bermula dari kedatangan peneliti ke . Setelah bertemu dan berbincang dengan kepala sekolah dan beberapa guru, peneliti mendapat informasi bahwa terdapat permasalahan dalam pembelajaran membaca Alquran di kelas V. Peneliti pun mendapat kesempatan untuk mengikuti kegiatan pembelajaran membaca Alquran di kelas V. Berbekal data dari guru kelas $\mathrm{V}$ dan hasil pengamatan kondisi pembelajaran membaca di kelas, peneliti mendiskusikan permasalahan tersebut dengan guru. Dari berbagai solusi pilhan yang ada, guru dan peneliti sepakat memilih penerapan metode CIRC sebagai solusi dari permasalahan yang ada. Berikut ini akan dibahas hasil pelaksanaan tindakan kelas membaca Alquran dengan menggunakan metode CIRC pada siklus I dan 2.

Hasil yang ada menunjukkan bahwa siswa berhasil mencapai standar ketuntasan belajar minimal yang telah ditentukan. Pada pratindakan siswa yang mencapai KKM hanya 57,90\%, sedangkan pada siklus 1 meningkat menjadi 68,42\%, dan terakhir pada siklus 2 meningkat menjadi $89,47 \%$. Data yang ada sudah menggambarkan kemampuan siswa dalam membaca 
Alquran, sehingga penelitian pun dilakukan hanya sampai siklus 2. Dari hasil penelitian di atas, terbukti bahwa penerapan metode CIRC ini dinilai berhasil dan dapat meningkatkan kemampuan membaca Alquran siswa. Yang paling penting dalam pengajaran Alquran ini ialah keterampilan membaca Alquran dengan baik sesuai dengan kaidah yang disusun dalam Ilmu Tajwid. Untuk dapat membaca dengan baik. Sebelum itu hendaknya sudah memahami dan dapat menggunakan berbagai tanda baca, dapat membunyikan symbol-simbol huruf dan kata sesuai dengan bunyi yang diucapkan oleh orang Arab. Kita mencontoh bunyi yang diucapkan oleh orang arab karena bahasa Alquran adalah bahasa Arab (Sapri, 2017: 48).

\section{KESIMPULAN}

Berdasarkan hasil penelitian dan pembahasan, dapat disimpulkan bahwa kemampuan membaca Alquran siswa kelas V SD Negeri 1 Sungai Ambawang dapat ditingkatkan melalui metode CIRC. Peningkatan tersebut terjadi pada proses dan produk. Peningkatan dalam hal proses dapat dilihat pada pelaksanaan proses pembelajaran yang berlamgsung secara menarik dan menyenangkan. Peningkatan proses juga meliputi keseluruhan perilaku siswa selama proses pembelajaran. Saat observasi pratindakan, dalam pembelajaran membaca Alquran siswa masih pasif dan kegiatan pembelajaran hanya berpusat pada guru. Setelah dilakukan tindakan siklus 1 dengan menggunakan metode CIRC dalam pembelajaran membaca Alquran, antusiasme siswa mulai muncul, akan tetapi hasil tindakan siklus 1 belum optimal karena masih ada beberapa siswa yang pasif selama kegiatan pembelajaran membaca Alquran sehingga perlu diadakan perbaikan tindakan pada siklus 2. Pada pelaksanaan siklus 2 agar siswa lebih antusias dan aktif dalam kegiatan membaca Alquran, maka guru menambah pemberian reward untuk tiga kelompok terbaik sehingga saat pembelajaran membaca Alquran berlangsung, siswa lebih aktif dan terlihat antusias. Hal ini menjadikan. pembelajaran membaca Alquran lebih kondusif dan menarik karena siswa lebih aktif. Peningkatan dalam hal tes dapat dilihat dari perbandingan nilai rata-rata tes membaca Alquran siswa pada tahap pratindakan dengan pascatindakan siklus II. Nilai rata-rata tes membaca Alquran pada tahap pratindakan sebesar 61,58. Nilai rata-rata tes membaca Alquran pada siklus II sebesar 81,58. Jadi, terjadi peningkatan rata-rata sebesar 20,00 .

\section{DAFTAR PUSTAKA}

Astuti., Rini . (2013). Peningkatan Kemampuan Membaca Al-Quran pada Anak Attention Deficit Disorder melalui Metode Al-Barqy Berbasis Applied Behavior Analysis. Jurnal pendidikan usia dini Volume 7 Edisi 2, November

Muhib \& Khair., Muhammad. (2005). Anakku Hafal Al-Qur'an. Solo: Qauna-Smart Media.

Purwanto., Ngalim., M. (2002). Psikologi Pendidikan. Bandung: Remaja Rosda Karya.

Rahim., Farida. (2007). Pengajaran Membaca di Sekolah Dasar. Jakarta: Bumi Aksara

Rosyid., Abd. (2019). Upaya Meningkatkan Kemampuan Membaca Al-Qur'an dengan Menggunakan Media Kartu Huruf pada Anak Usia Dini di RA Nuris Sufyan Liridlalla. Jurnal Pendidikan Anak Usia Dini. Vol. 01 No. 02, Desember.

Santoso., Wijaya., Heru. (2007). Eksperimen Penggunaan Metode Konvensional dan Metode SQ3R dalam Pembelajaran Kemampuan pada Siswa Kelas Satu SLTP di Kutoarjo. Tesis: IKIP Yogyakarta

Sapri. (2017). Pengaruh disiplin dan motivasi terhadap hasil belajar siswa pada pembelajaran seni Tilawah Alquran di Pondok Pesantren Darul Hidayah Rasau Jaya Kabupaten Kubu Raya. Tesis: IAIN Pontianak 